\title{
3M Heavy Duty Roto Peen: Baseline Report
}

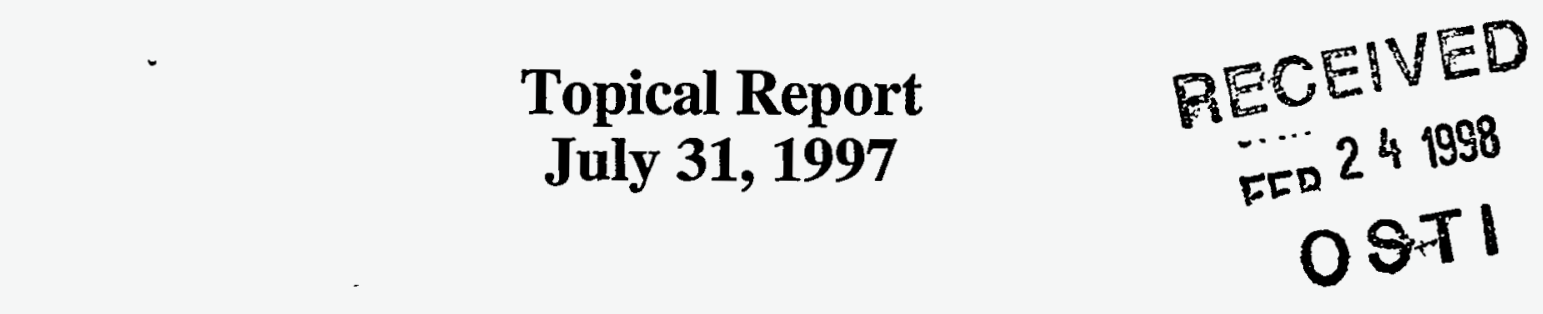

\section{2}

Work Performed Under Contract No.: DE-FC21-95MC32260

For

U.S. Department of Energy

Office of Environmental Management

Office of Technology Development

1000 Independence Avenue

Washington, DC 20585
U.S. Department of Energy

Office of Fossil Energy

Federal Energy Technology Center

Morgantown Site

P.O. Box 880

Morgantown, West Virginia 26507-0880

DISTAZUUTON OF THIS DOCUMENT IS UNAMIEO

By פTC QUALTYY IISPITUPD \&

Operating Engineers National Hazmat Program

250 Airport Circle

Beaver, West Virginia 25813 


\section{DISCLAIMER}

Portions of this document may be illegible electronic image products. Images are produced from the best available original document. 


\section{M HEAVY-DUTY ROTO PEEN}

\section{TABLE OF CONTENTS}

SECTION 1 SUMMARY $\ldots \ldots \ldots \ldots \ldots \ldots \ldots \ldots \ldots \ldots \ldots \ldots \ldots \ldots \ldots \ldots \ldots \ldots$

TECHNOLOGY DESCRIPTION $\ldots \ldots \ldots \ldots \ldots \ldots \ldots \ldots \ldots \ldots \ldots$

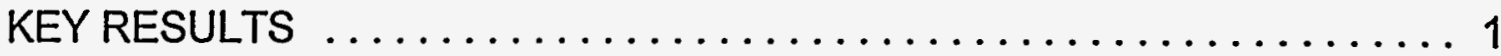

SECTION 2 -TECHNOLOGY DESCRIPTION $\ldots \ldots \ldots \ldots \ldots \ldots \ldots \ldots \ldots \ldots$

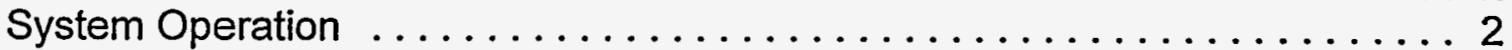

SECTION 3 - HEALTH AND SAFETY EVALUATION $\ldots \ldots \ldots \ldots \ldots \ldots \ldots$

General Health and Safety Concerns $\ldots \ldots \ldots \ldots \ldots \ldots \ldots \ldots \ldots$

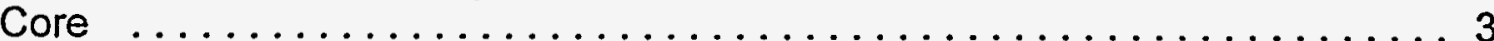

Best Management Practices $\ldots \ldots \ldots \ldots \ldots \ldots \ldots \ldots \ldots \ldots \ldots \ldots$

Industrial Hygiene Monitoring . . . . . . . . . . . . . . . . . 5

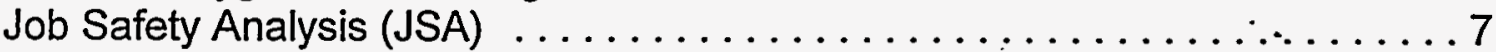

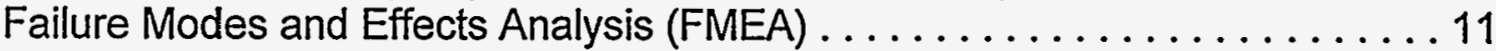

Technology Safety Data Sheet (TSDS) . . . . . . . . . . . . . . . 18

Human Factors Interface ........................... 19

Emergency Response/Preparedness . .................. 19

SECTION 4 - TECHNOLOGY APPLICABILITY $\ldots \ldots \ldots \ldots \ldots \ldots \ldots \ldots \ldots$

SECTION 5 - REGULATORYIPOLICY ISSUES $\ldots \ldots \ldots \ldots \ldots \ldots \ldots \ldots \ldots$

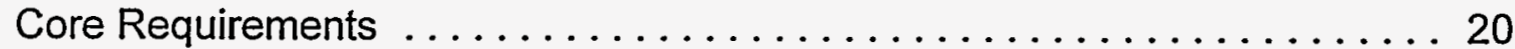

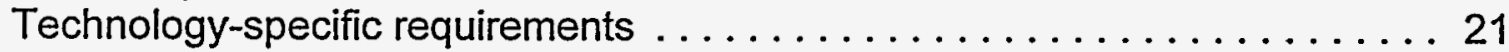

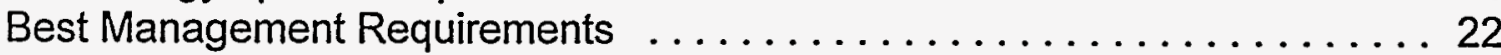

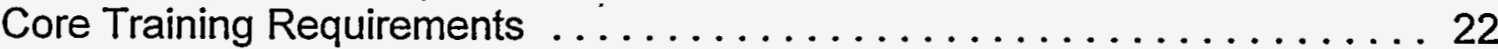

Technology-specific Training . . . . . . . . . . . . . . . . . . 23

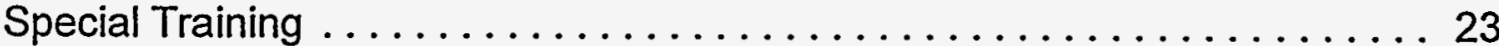

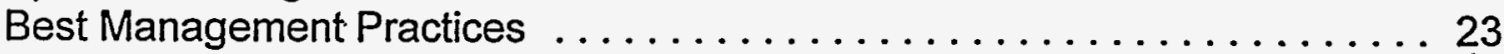

SECTION 6 - OPERATIONAL CONSIDERATIONS AND

RECOMMENDATIONS ........................ 23

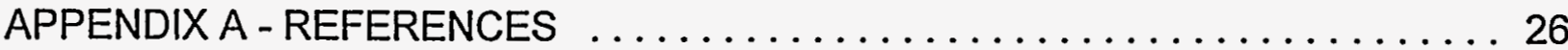

APPENDIX B - INDUSTRIAL HYGIENE DATA $\ldots \ldots \ldots \ldots \ldots \ldots \ldots \ldots \ldots \ldots$ 


\section{M Heavy-Duty Roto PeEN \\ HUMAN FACTORS EVALUATION}

\section{SECTION 1 - SUMMARY}

\section{TECHNOLOGY DESCRIPTION}

The heavy-duty roto peen technology was being evaluated at Florida International University (FIU) as a baseline technology. It is a commercially available technology and has been used for various projects at locations throughout the country. In conjunction with FIU's evaluation of efficiency and cost, this report covers the human factors assessment for safety and health issues.

The heavy-duty roto peen allows for the selective removal of concrete substrates. The peen is a tungsten carbide shot brazed to a hardened steel rivet that is supported by a heavy-duty flexible flap. The shot rivet is kept captive to the tool by mounting the roto peen in a slotted hub. The heavy-duty roto peen is designed to be used with several commercially available pieces of equipment. The equipment being used will determine the width of each pass. The equipment being used with the roto peen is then connected to a vacuum system for dust collection during scabbling.

\section{KEY RESULTS}

The safety and health evaluation during the human factors assessment focused on two main areas: noise and dust. The dust exposure was found to be minimal, but noise exposure was of importance. Further testing for each of these exposures is recommended, because the outdoor environment where the human factors assessment took place may skew the results. It is feasible that the dust and noise levels will be higher in an enclosed operating environment. Other areas of concern found were armhand vibration, ergonomics, tripping hazards, electrical hazards, machine guarding, and lockout/tagout. 


\section{SECTION 2 \\ TECHNOLOGY DESCRIPTION}

\section{SYSTEM OPERATION}

The heavy-duty roto peen technology was being evaluated at Florida International University (FIU) as a baseline technology. It is a commercially available technology and has been used for various projects at locations throughout the country. In conjunction with FIU's evaluation of efficiency and cost, this report covers the human factors assessment conducted for safety and health issues.

The heavy-duty roto peen is a technology that allows for the selective removal of concrete substrates. The heavy-duty roto peen is a tungsten carbide shot brazed to a hardened steel rivet that is supported by a heavy-duty flexible flap material. The shot rivet is kept captive to the tool by mounting the roto peen in a slotted hub. The peens are held in place in the hub slots by a metal or plastic pin inserted through the flap loop. A

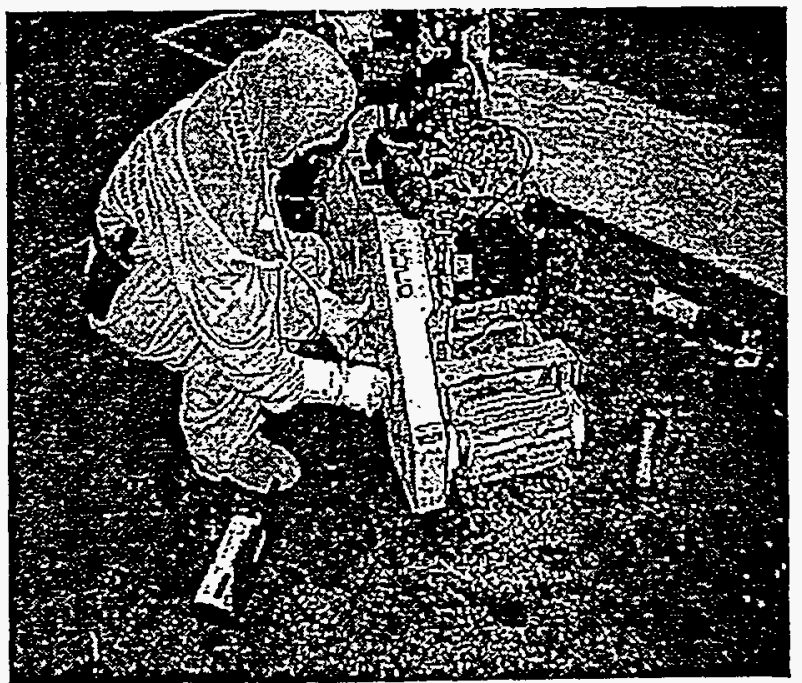

Figure 1 - Adjusting drum height from concrete before beginning scabbling operation. ring is then placed over each end of the hub to secure the peens in place. Each slot is offset to allow for the greatest rivet contact with the surface being removed.

The heavy-duty roto peen is designed to be used with several commercially available pieces of equipment. The equipment being used will determine the width of each pass. During the concrete demonstration, the heavy-duty roto peen was used with the EDCO CPU-10-C, EDCO CPM-4, and a DESCO MiniFlushplate. These pieces of equipment are capable of a 10-inch, 5-inch, and 2 - inch width respectively. The machines used were connected to a vacuum system that collected dust as surface coating and substrate were removed. During the demonstration, the equipment was 12 used with a Tornado Vacuum which directs the dust generated into a 55-gallon drum

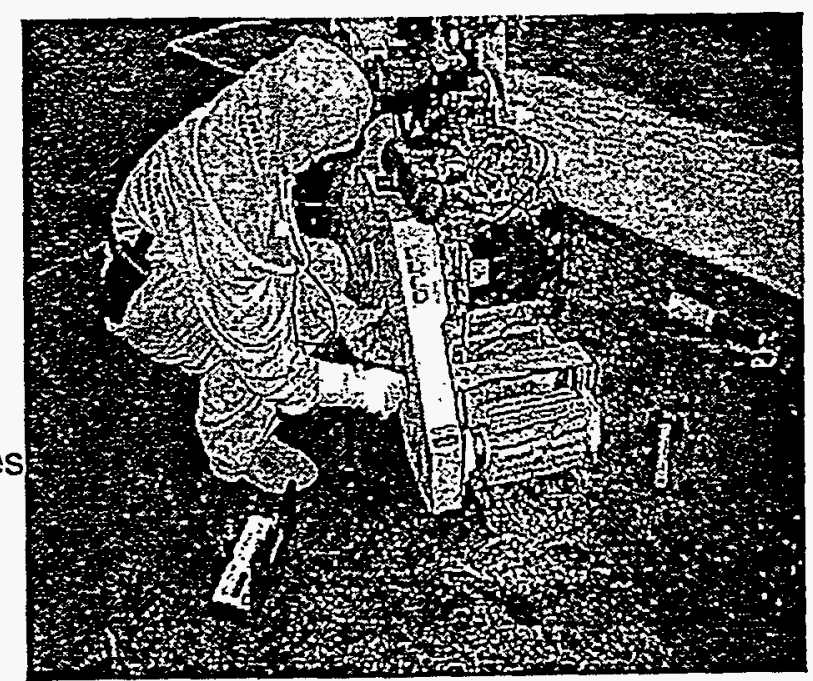

Figure 2 - Adjusting drum height from concrete before beginning scabbling operation. 
collection system. The Tornado vacuum system did not use high-efficiency particulate air (HEPA) filters. The equipment used with the heavy-duty roto peen can be used with a HEPA vacuum system. The HEPA system would enable collection of smaller particles of dust.

The operator did not encounter difficulties with equipment operation while dressed out in the appropriate PPE. The technology coupled with the commercially available equipment described above did present a substantial noise hazard. These as well as other safety and health factors will be discussed in greater detail in other sections of this report.

The EDCO CPU-10-C unit left some grease on the concrete pad during operation. In an environment with alpha-contaminated concrete, this could create a secondary contamination. Routine preventive maintenance must be an intrinsic part of the decontamination and decommissioning (D\&D) process to prevent this type of secondary contamination created by the technology itself.

\section{SECTION 3 \\ HEALTH AND SAFETY EVALUATION}

\section{GENERAL SAFETY AND HEALTH CONCERNS}

Personnel where the heavy-duty roto peen technology is being used need to be concerned with two categories of safety and health issues. Core issues are those based on current safety and health regulatory requirements. Best management practices are related to issues that are not based on current safety and health regulations, but are key to preventing worker injury and illness on the job.

Safety and health issues of concern with the heavy-duty roto peen technology included:

\section{Core Issues}

Tripping hazards - the electrical cords and vacuum hoses needed to operate the equipment are tripping hazards. Therefore, the need for stringent housekeeping must be evaluated.

- Electrical hazards - the generator and electrical cords necessary to operate the equipment can present electrical hazards. Therefore, the need for ground fault circuit interrupters, grounding, and strain relief must be evaluated.

Rotating machinery - the left axle on the EDCO CPU-10-C presented a rotating part where a worker could place a finger or fingers while the equipment is operating and cause serious injury, Therefore, the need for machine guarding must be evaluated. While this concern is specific to the EDCO CPU-10-C, 
exposed rotating machinery needs to be addressed for any piece of equipment where the heavy duty roto peen may be used.

- Lockout/Tagout - the user of the technology coupled with any commercially available equipment will need to develop a lockout/tagout program to assure there is not an accidental release of energy during maintenance/repair activities.

Noise - the operator is subjected to noise at a level that would require inclusion in a hearing conservation program while operating all of the equipment used with the heavy-duty roto peen during the testing demonstration.

- Dust - the equipment generated some visible dust during operation but mostly at the scabbling head instead of in the breathing zone of the operator. The amount of dust generated in the breathing zone of the operator may change based on . the environment in which the concrete decontamination is taking place, therefore, the user of the technology will need to develop a sampling plan based on individual site needs.

\section{Best Management Practices:}

- Hot surfaces - the muffler on the propane powered equipment gets hot and is a burn hazard. Therefore, the worker needs to be made aware of its potential to cause injury. In addition, the heat being given off by the muffler has the potential to add to the overall heat stress if the operation is being conducted in an enclosed environment.

- Heat stress - the operator was subjected to an increase in heat stress due to the need to utilize Anti-C PPE. The user will need to develop a heat stress program for the environment in which the technology is being used, taking into consideration any PPE that may need to be utilized.

- Ergonomics - the user was subjected to ergonomic stressors that need to be taken into consideration, such as, stooping, bending, twisting, kneeling, and lifting:

- Arm-hand vibration - the user was subjected to arm-hand vibration while operating all of the equipment used with the heavy-duty roto peen during the testing demonstration.

- Communication - due to the noise generated by the technology and the equipment during operation, communication may be difficult. Personnel working in the area should be familiar with and use hand signals when needed. 


\section{INDUSTRIAL HYGIENE MONITORING}

During the testing demonstration with the heavy-duty roto peen, sampling was conducted for dust and noise. In addition, the wet-bulb globe temperature was monitored to evaluate heat stress. Observational evaluation was conducted for ergonomics and arm-hand vibration.

The potential for ergonomic problems was evaluated by observation during the testing demonstration. There is potential for muscle/back stress and/or injuries due to bending, twisting, and lifting during the setup, operation, maintenance, and decontamination of the equipment used with the heavy-duty roto peen. There is potential for stress on and/or injury to the knees due to the kneeling and stooping required during setup, operation, maintenance, and decontamination activities. The potential for back and knee stress was most evident during operation of the DESCO MiniFlushplate since it is a hand operated tool and the operator must bend, stoop, or kneel during use.

During the testing demonstration arm-hand vibration exposure was present. While armhand vibration was not quantitatively measured, it was readily apparent that there was exposure to arm-hand vibration that could potentially cause problems such as Raynaud's syndrome.

Heat stress was monitored using a Quest QuestTemp ${ }^{\circ} 15$ Heat Stress Monitor. The wet-bulb globe temperature was used to determine a work/rest regimen in accordance with the American Conference of Governmental industrial Hygienist (ACGIH) recommendations. The wet-bulb globe temperature was adjusted for the type of clothing, including PPE, that the worker was wearing.

In addition, the worker's blood pressure, pulse, and temperature were monitored throughout the day. No problems were encountered due to heat stress, but the worker's level of discomfort was increased when wearing the Anti-C PPE. While heat stress will be increased while wearing PPE, the overall heat stress response will vary from worker to worker. Each situation in which the current technology is used will need to be evaluated for the heat stress potential, taking into consideration the wet-bulb globe temperature, PPE in use, physical condition of the worker, and workeracclimatization.

Dust monitoring was conducted with a sampling train consisting of an SKC IOM Inhalable dust sampler coupled with a MSA Escort Elf air sampling pump. Pre-and post-sampling calibration was accomplished using a BIOS International DryCal DC1 primary calibration system. Sampling filters were desiccated pre- and post-sampling and weighed on a Denver Instrument Company A-200DS scale. Sampling was conducted in accordance with NIOSH Method 0500. 
Personal sampling was conducted on the equipment operator, and area sampling was done at the head of the scabbler. Personal dust sampling results of $0.7463 \mathrm{mg} / \mathrm{m}^{3}$ and $3.1566 \mathrm{mg} / \mathrm{m}^{3}$ and area sampling results of $1.6367 \mathrm{mg} / \mathrm{m}^{3}$ and $5.4765 \mathrm{mg} / \mathrm{m}^{3}$ were obtained. These values do not exceed the Occupational Safety and Health Administration (OSHA) permissible exposure limit (PEL) or the ACGIH threshold limit value (TLV) of $15 \mathrm{mg} / \mathrm{m}^{3}$ and $10 \mathrm{mg} / \mathrm{m}^{3}$ respectively for total dust. Occasionally visible dust was produced at the head of scabbler and from the collection bags on the vacuum unit. According to the operator, this was due to the high humidity and the fact that a HEPA filter vacuum was not being utilized. Due to this and the dust sampling being conducted in an outdoor environment with windy conditions, it is recommended that sampling be conducted while the scabbling operation is being conducted in an enclosed environment. A complete air sampling plan for a site would need to be developed to include not only dust but other contaminants specific to the concrete decontamination project, including the constituents of the concrete (e.g., silica).

Personal noise monitoring was conducted using Metrosonic dB-3100 data logging noise dosimeters. Monitoring was conducted for 2.9 hours (174 minutes) during the scabbling operation. Monitoring during this time showed a noise dose of $130.05 \%$, which gives an 8-hour time-weighted average (TWA) of $91.9 \mathrm{dBA}$. The OSHA allowable PEL for noise is a $100 \%$ dose or an 8 -hour TWA of $90 \mathrm{dBA}$. The operator of the scabbling equipment coupled with the heavy-duty roto peen was overexposed after 2.9 hours of operation. If the operator continued to have the same level of noise exposure during the 8-hour shift, a projected 8-hour TWA would produce a noise dose of $353.69 \%$, or an 8 -hour TWA of $99.1 \mathrm{dBA}$. At these exposure levels, personnel would be required to be included in a hearing conservation program. Feasible engineering controls, administrative controls; and personal protective equipment (PPE-hearing protection devices) need to be used. The percentage of time spent at each loudness level that comprises the exposure can be seen in Appendix B.

During the 2.9 hours of operations, the noise levels were averaged for each oneminute period of time and then an overall average of each one-minute period was calculated which resulted in an average exposure level of $99.1 \mathrm{dBA}$ for an $80 \mathrm{~dB}$ cutoff level and $99 \mathrm{dBA}$ for a $90 \mathrm{~dB}$ cutoff level. OSHA requires an $80 \mathrm{db}$ cutoff for hearing conservation measurements, and a $90 \mathrm{db}$ cutoff for engineering controls compliance measurements. The maximum sound level observed during the measurement period was $129.2 \mathrm{dBA}$, and the highest instantaneous sound pressure level was over $140 \mathrm{~dB}$. These measurements define noise as a significant exposure for personnel operating the scabbling equipment. It must also be noted that the equipment was being operated in an open outdoor environment at the time of the measurements, and operation in an enclosed facility would have the potential to increase the noise level due to other influences such as vibration and reverberation. Therefore, it is recommended that noise monitoring be conducted while the equipment is being operated in an enclosed environment. 


\section{JOB SAFETY ANALYSIS 3M HEAVY-DUTY ROTO PEEN}

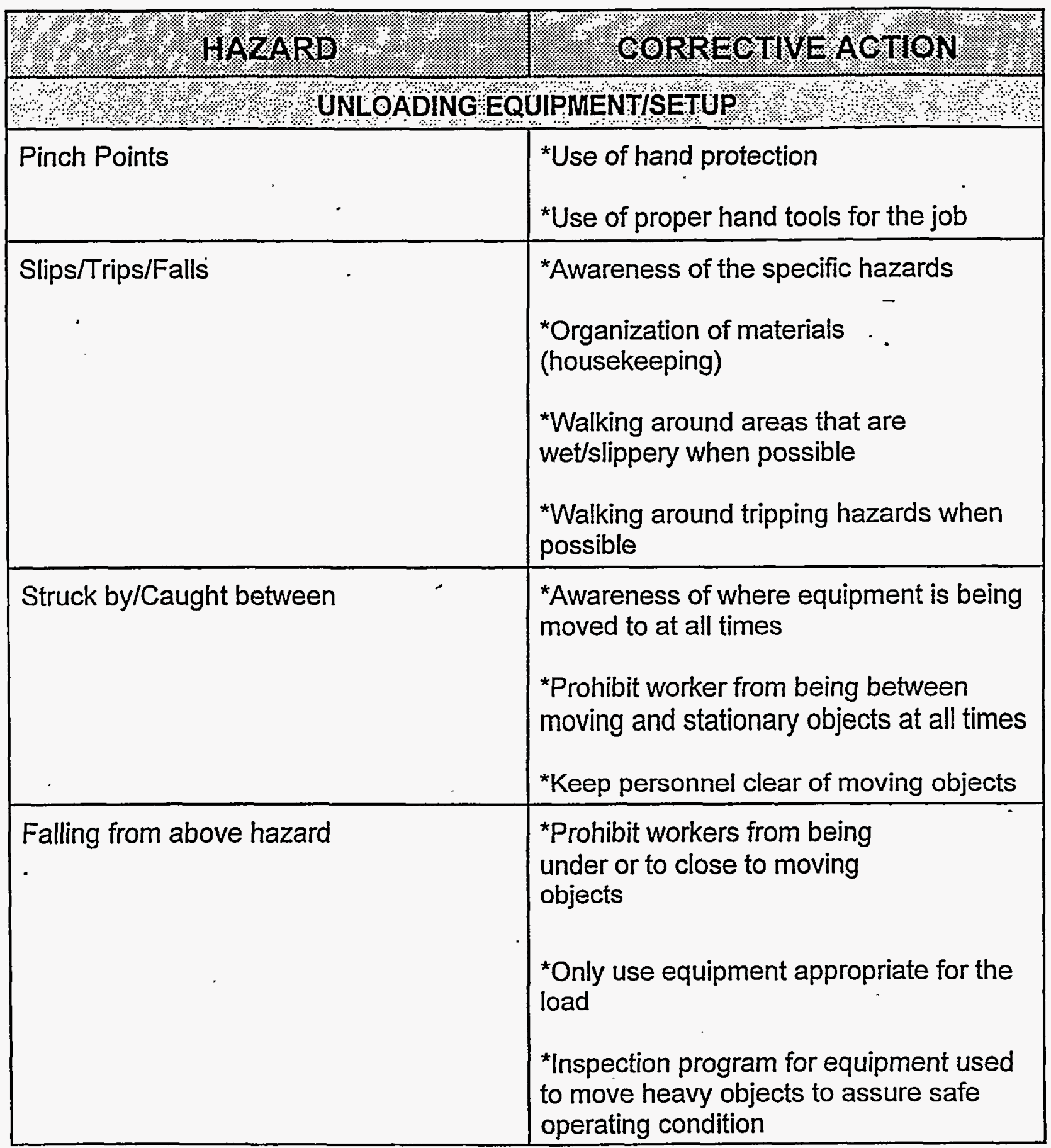




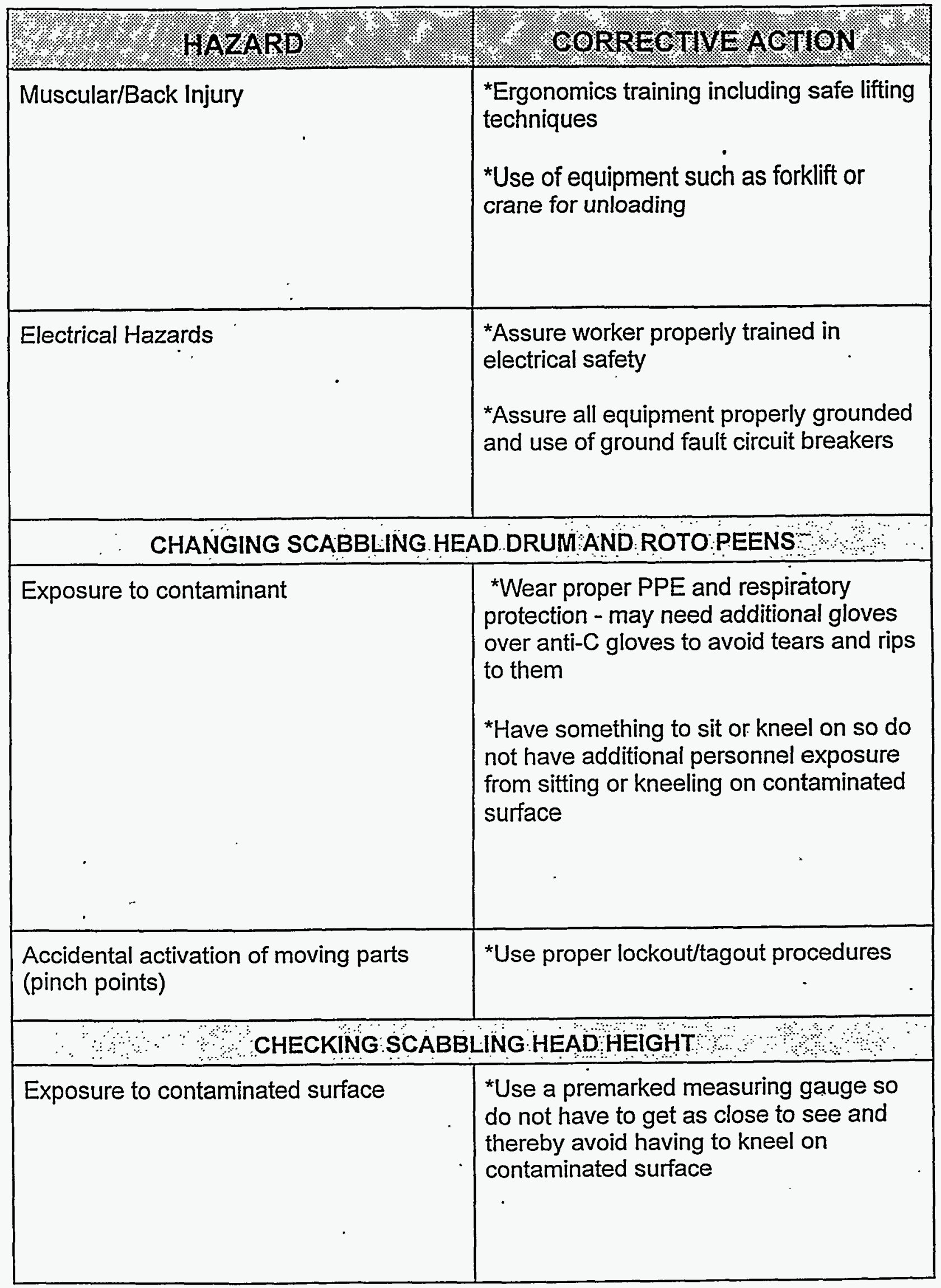




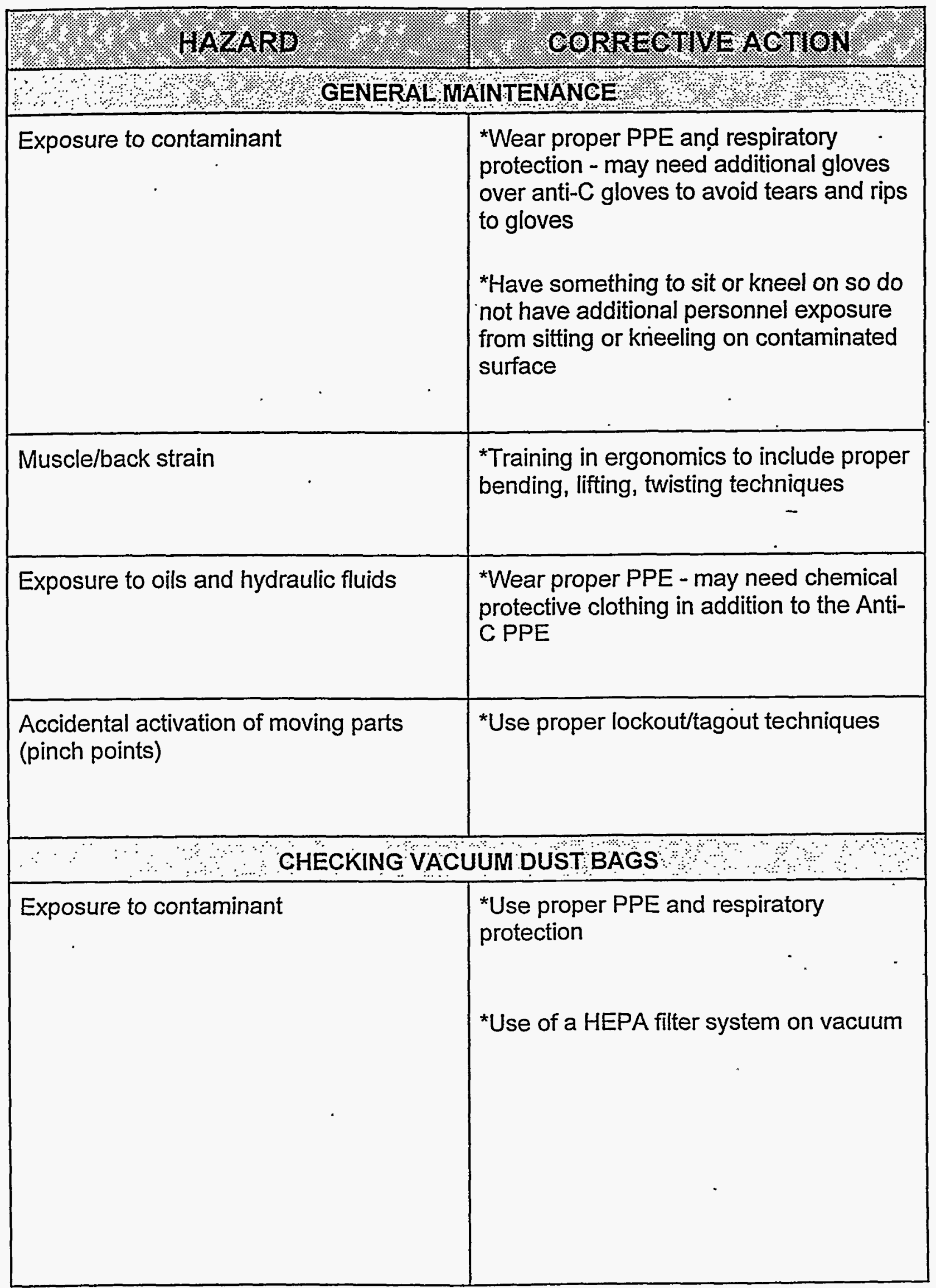




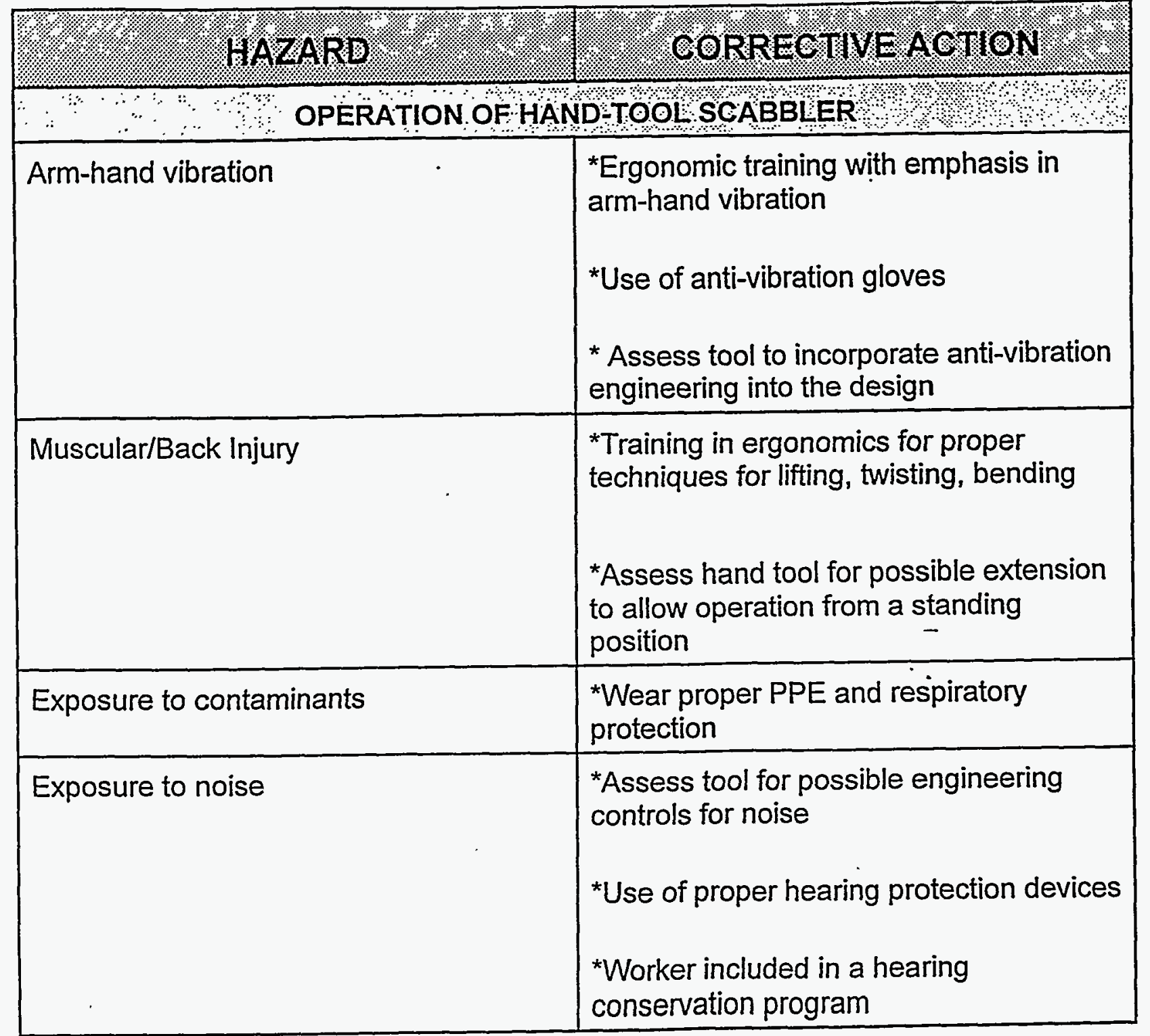




\section{FAILURE MODES AND EFFECTS ANALYSIS 3M HEAVY-DUTY ROTO PEEN*}

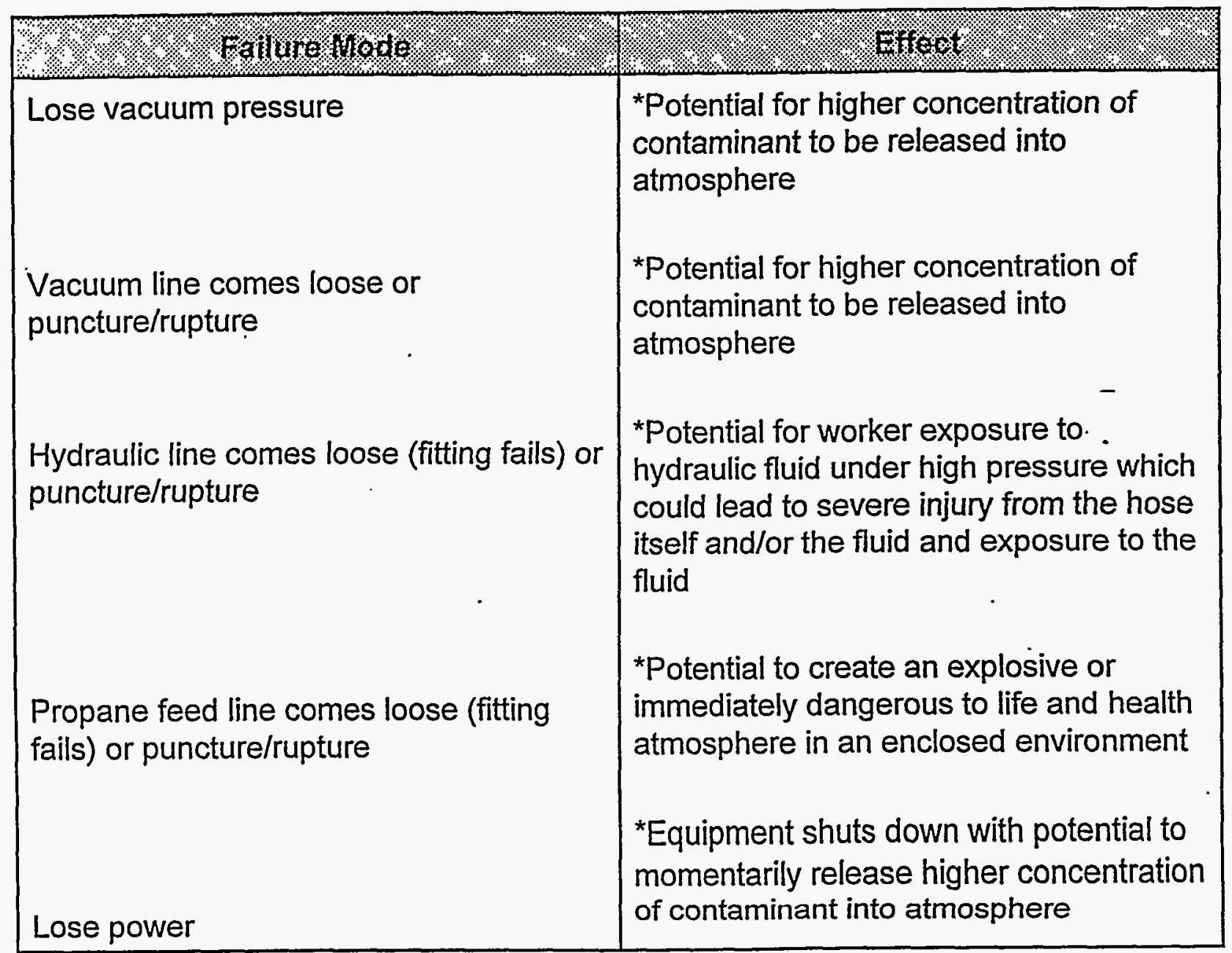

*The FMEA addresses the equipment the heavy-duty roto peen was coupled with during the evaluation. The roto peen itself does not pose these failure modes. 


\section{TECHNOLOGY SAFETY DATA SHEET 3M HEAVY-DUTY ROTO PEEN}

\begin{tabular}{|c|c|}
\hline SECTION 1: TECHNOLOGY IDENTITY & \\
\hline Manufacturer's Name and Address: & $\begin{array}{l}\text { Emergency Contact: } \\
\text { Bill Harding (EDCO) }\end{array}$ \\
\hline $\begin{array}{l}3 M \\
3 M \text { Center }\end{array}$ & $1-800-638-3326$ \\
\hline $\begin{array}{l}\text { Abrasive Systems Division } \\
\text { 223-6N-01 } \\
\text { St. Paul, MN 55133-3220 }\end{array}$ & $\begin{array}{l}\text { Information Contact: } \\
\text { Bill Harding (EDCO) } \\
1-800-638-3326\end{array}$ \\
\hline & Date Prepared: \\
\hline $\begin{array}{l}\text { Other Names: } \\
\text { Heavy-duty Roto Peen scabbling heads } \\
\text { Roto Peen scabbling heads }\end{array}$ & Signature of Preparer: \\
\hline
\end{tabular}

\section{SECTION 2: PROCESS DESCRIPTION}

The heavy-duty roto peen allows for the selective removal of concrete substrates. The heavy-duty roto peen is a tungsten carbide shot brazed to a hardened steel rivet that is supported by a heavy-duty flexible flap material. The shot rivet is kept captive to the tool by mounting the roto peen in a slotted hub. The peens are held in place in the hub slots by a metal or plastic pin inserted through the flap loop. A ring is then placed over each end of the hub to secure the peens in place. Each slot is offset to allow for the greatest rivet contact with the surface being removed.

The heavy-duty roto peen is designed to be used with several commercially available pieces of equipment. The machine being used will determine the width of 
each pass. During the concrete demonstration the heavy-duty roto peen was used with the EDCO CPU-10-C, EDCO CPM-4, and a DESCO MiniFlushplate. These pieces of equipment are capable of a 10 inch, 5 inch, and 2 inch width respectively. The pieces of equipment used were connected to a vacuum system that collected dust as substrate was removed.

\section{SECTION 3: PROCESS DIAGRAM}

A process diagram is not available from the manufacturer for the heavy-duty roto peen. To be able to understand the process for using the heavy-duty roto peen, a process diagram should be obtained from the manufacturer of the scabbling equipment before use.

\section{SECTION 4: CONTAMINANTS AND MEDIA}

The heavy duty roto peen has the potential to cause concrete dust and associated contaminants to become airborne. Specific contaminants need to be evaluated on a site by site, job by job basis to determine the potential for exposure.

\section{SECTION 5: ASSOCIATED SAFETY HAZARDS}

Probability of Occurrence of Hazard:

$1 \quad$ Hazard may be present but not expected over background level

2 Some level of hazard above background level known to be present

3 . High hazard potential

4 Potential for imminent danger to life and health

A. ELEOTRICAL (LOCKOUTIAGOUT)

RISK RATING: 2

The heavy duty roto peen itself does not require electricity to be used but the equipment it is coupled with may. In this case assure proper grounding of all equipment. Compliance with applicable electrical standards and codes and lockout/tagout procedures must be followed to assure the safety of personnel. 
The Heavy duty roto peen does not pose this threat in and of itself. Care should be taken when using the heavy duty roto peen with propane powered equipment. $A$. release of propane could cause an explosive or toxic atmosphere. Site characterization should determine the need for air monitoring and instrumentation of lower explosive limits or airborne contaminants.

The roto peen cannot be used in an explosive atmosphere due to its potential to cause sparking.

C. CONFINED SPACE ENTRY

RISK RATING: 1

Not part of this technology unless the specific location where scabbler is being used is a confined space. In this case, confined space procedures would need to be followed.

D. MECHANICAL HAZARDS RISK RATING: 4

Use of large equipment and hand tools may pose the following: pinch points, struck by, and caught between hazards and fall from above.

\section{E. PRESSURE HAZARDS}

RISK RATING: 4

The Heavy duty roto peen does not pose this threat in and of itself but the equipment it is coupled with may require the use of high pressure hydraulic and/or air lines.

F. TRIPPING AND FALLING RISK RATING: 3

Vacuum hoses, electrical cords, hydraulic lines (when present), and air lines (when present) present tripping hazards.

G. LADDERS AND PLATFORMS

Not part of this technology.

H. MOVVING VEHICLES

RISK'RATING: 3

The presence of multiple pieces of mobile equipment (used to unload and load the equipment) in relationship to a small area of operation may pose a hazard. Sufficient warning devices such as horn, bells, lights and back up alarms should be utilized. Personnel should be trained to work with and around moving equipment.

1. BURIED UTILITIES, DRUMS, AND TANKS RISK RATING: N/A

Not part of this technology. 


\begin{tabular}{|c|c|}
\hline \multicolumn{2}{|l|}{ SECTION 5: ASSOCIATED SAFETY HAZARDS } \\
\hline JPROTRODING OBJECTS & RISK RATING: N/A \\
\hline \multicolumn{2}{|l|}{ Not part of this technology. } \\
\hline K GAS CYLINDERS & RISK RATING: 4 \\
\hline \multicolumn{2}{|c|}{$\begin{array}{l}\text { May be present when a propane powered piece of equipment is being used. } \\
\text { Potential to produce explosive or immediately dangerous to life and health } \\
\text { atmosphere in an enclosed environment. }\end{array}$} \\
\hline LTRENCHINGANEEXCAVATIONS & RISK RATING: N/A \\
\hline \multicolumn{2}{|l|}{ Not part of this technology. } \\
\hline M OVERHEAR LIFIS & RISK RATING: 4 \\
\hline \multicolumn{2}{|c|}{$\begin{array}{l}\text { Unloading and loading of equipment may require overhead lifts or the use of a forklift. } \\
\text { Proper precautions indicated. }\end{array}$} \\
\hline No OVERHEAD HAZZARDS । & RISK RATING: 2 \\
\hline
\end{tabular}

\section{SECTION 6: ASSOCIATED HEALTH HAZARDS}

\begin{tabular}{|l|l|l}
\hline A. INHALATIONHAZARD & RISK RATING: 3 \\
\hline
\end{tabular}

Technology produces dust from the concrete and concrete contamination. Specific hazards will be identified from the site characterization. Evaluation of total dust and/or respirable dust generated should be evaluated. Propane powered equipment could present a hazard.

\begin{tabular}{|l|l|l|}
\hline B SKIN ABSORPTION \\
\hline
\end{tabular}

This would be dependent on the contaminants at the site and would be identified by the site characterization. Hydraulic fluid could present a hazard.

\begin{tabular}{ll|l|l|}
\hline C. HEATSTRESS \\
\hline
\end{tabular}

Ambient atmospheric conditions correlated with PPE levels must be considered.

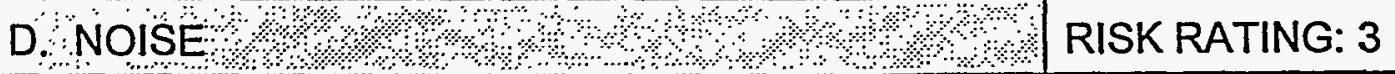

The heavy duty roto peen and the equipment it is being coupled with present a high noise hazard. 
SECTION 6: ASSOCIATED HEALTH HAZARDS

E. NON-IONIZING RADIATION

RISK RATING: NIA

Not part of this technology.

F. IONIZING RADIATION

RISK RATING: $1-4$

None associated with this technology but the contaminated concrete may present a significant radiation exposure. This will be identified by the site characterization.

G. COLD STRESS

RISK RATING: 1

Technology does not produce a hazard, but ambient conditions need to be considered.

H. ERGONOMIC HAZARDS

RISK RATING: 3

Poses ergonomic hazards associated with lifting, bending, twisting, stooping, kneeling. These may cause injury/strain to the back, knees, hips, and/or legs.

1. OTHER

RISK RATING: 3

Poses a hazard due to arm-hand vibration from operating the equipment to which the roto peen is coupled. This may lead to associated problems such as Raynaud's Syndrome.

\section{SECTION 7: PHASE ANALYSIS}

A. CONSTRUCTION/START-UP

The set-up/start-up phase presents several hazards including pinch points, slips/trips/falls, struck by/caught between, falling from above, muscular/back injury, and electrical.

B. OPERATION:

The operational phase presents several hazards including exposure to contaminant (airborne and from the surface), arm-hand vibration, muscular/back injury, and exposure to noise.

\section{MAINTENANCE}

The maintenance phase presents several hazards including pinch points, slips/trips/falls, struck by/caught between, muscular/back injury, electrical, exposure to contaminants (airborne and from the surface), exposure to hydraulic fluids, and accidental activation of moving parts. 


\section{SECTION 7: PHASE ANALYSIS}

D. DECOMMISSIONING

The decommissioning phase presents several hazards including exposure to the contaminant, pinch points, slips/trips/falls, and muscular/back injury.

\section{SECTION 8: HEALTH AND SAFETY PLAN REQUIRED ELEMENTS}

A. AIR MONITORING

When concrete is scabbled, total dust and respirable dust need to be monitored. Monitoring also needs to be done for specific concrete contaminants and may need to be conducted for specific constituents of the concrete such as silica. In addition, noise monitoring is essential.

B. WORKER TRAINING

Training that would apply in this case may include but not be limited to: HAZWOPER (Hazardous Waste Operations and Emergency Response), HAZCOM (Hazard Communication), Respiratory Protection, Hearing Conservation, Ergonomics (proper lifting, bending, stooping, kneeling, arm-hand vibration), Heat stress (learning to recognize signs and symptoms), Personal Protective Equipment, Job specific training for equipment operation, CPR/First Aid/Emergency Response/Blood-borne Pathogens, Electrical Safety, Lockout/Tagout, Radiation Safety, Hand Signal Communication, Construction Safety (OSHA 500) and or General Industry Safety (OSHA 501)

\section{EMERGENCY RESPONSE}

Emergency response planning for a site needs to assure adequate coverage for hazards described in the TSDS. Having as many workers as possible trained in CPR and first aid is recommended.

D. MEDICAL SURVEIL ANCE

Evaluation of personnel's general health with emphasis on the cardiovascular and respiratory system, back, and peripheral nervous system. Annual audiograms.

E. INFORMATIONAL PROGRAM

Workers must be trained in specific operation of equipment before use. 
SECTION 9: COMMENTS AND SPECIAL CONSIDERATIONS

Due to the high levels of noise produced, communication may become difficult. Personnel working in the area should be familiar with and use hand signals as necessary.

Only personnel who have been adequately trained in the operation of this technology. should be permitted to operate and/or work with the equipment. 


\section{HUMAN FACTORS INTERFACE}

The technologies being tested for concrete decontamination and decommissioning are targeted for use on alpha-contaminated concrete. Therefore, the equipment operator was dressed out in Anti-C (alpha radiation) PPE which included cloth suit, hood, inner and outer boots, inner and outer gloves, and full face air-purifying respirator. The fullface respirator created some visibility problems for the operator while wearing Anti-C PPE. In addition, the need to perform work in the Anti-C PPE caused some increase in heat stress for the operator.

If the concrete being decontaminated has contamination other than or in addition to alpha radiation, additional levels of protection, such as level A or level B PPE, may be required for the operator. These may create additional human interface problems, such as a greater decrease in visibility and manual dexterity, an increase in heat stress, and an overall increase in physical stress. It is recommended that additional safety and health evaluations be conducted utilizing these higher levels of protection.

Of concern is the ability of the equipment coupled with the heavy-duty roto peen to continue to run without operator control. This could lead to serious injury for the operator or other workers in the area. A mechanism such as a dead man switch would address this potential for injury.

\section{EMERGENCY RESPONSE/PREPAREDNESS}

The use of the $3 \mathrm{M}$ heavy-duty roto peen scabbling technology would not be applicable to emergency response.

Emergency response/preparedness must be part of every hazardous waste site safety and health plan. In addition to credible site emergencies, site personnel must plan for credible emergencies in connection with the heavy-duty roto peen and associated equipment.

All precautions used when responding to an emergency situation at the site will apply. Before entering an area where to roto peen is being used with other equipment, the equipment needs to be completely shut down (de-energized).

If the equipment being used is propane-powered and an incident occurs, special attention must be paid to monitoring for explosive levels and oxygen levels in any enclosed area that must be entered to provide assistance and/or rescue. 


\section{SECTION 4 \\ TECHNOLOGY APPLICABILITY}

On observation, the technology did deposit some visible dust into the atmosphere. Air monitoring did not show a significant dust level, but this was difficult to assess due to the windy outdoor testing environment. Most of the visible dust that was seen was generated when the scabbling head was lifted and by the vacuum system dust bags. The system needs to be evaluated to determine if increasing vacuum air flow or raising the scabbling head slower would reduce dust generation. Additionally, when scabbling concrete, the system must be used with a HEPA filter system.

The technology itself would not be difficult to decontaminate or it could be considered a consumable at the completion of the project. The equipment it was coupled with during the testing demonstration would have to be torn down to be decontaminated. This will not necessarily guarantee that decontamination for alpha will be complete. It will be difficult to survey for alpha contamination due to all of the small spaces in the equipment that are hard to reach with a probe.

\section{SECTION 5 REGULATORYIPOLICY ISSUES}

The site safety and health personnel where the heavy-duty roto peen technology and associated equipment is being used need to be concerned with safety and health regulations applicable to the issues discussed above. Regulations that apply may be divided into four categories. Core requirements are those regulations that would apply to any hazardous waste work site, regardless of the type of job. Technology-specific requirements are those regulations that apply due to the specific technology being used. Special requirements are standards and policies that are specific to the technology itself and are required by reference in a regulation. Best management practices are not required, but are recommended, by organizations such as the American National Standards Institute (ANSI), the National Institute of Occupational Health and Safety (NIOSH), Department of Energy (DOE), National Fire Protection Association (NFPA), etc. These regulations/standards may include but not be limited to the following:

Core requirements:

- OSHA 29 CFR 1926.25 Housekeeping

$+\quad$ OSHA 29 CFR 1910.141 Sanitation (1910.141(a)(3) covers housekeeping) 
- OSHA 29 CFR 1926.53 lonizing Radiation

- OSHA 29 CFR 1910.96 lonizing Radiation

- OSHA 29 CFR 1926 Subpart Z Toxic and Hazardous Substances

OSHA 29 CFR 1910 Subpart Z Toxic and Hazardous Substances

- OSHA 29 CFR 1926.59 Hazard Communication

OSHA.29 CFR 1910.1200 Hazard Communication

- OSHA 29 CFR 1926.64 Process Safety Management of Highly Hazardous Chemicals

- OSHA 29 CFR 1910.119 Process Safety Management of Highly Hazardous Chemicals

- OSHA 29 CFR 1926.65 Hazardous Waste Operations and Emergency Response

- OSHA 29 CFR 1910.120 Hazardous Waste Operations and Emergency Response

Occupational Safety and Health Act 1970(5)(a)(1) General Duty Clause

Technology-specific requirements:

$+\quad$ OSHA 29 CFR 1926 Subpart K Electrical

OSHA 29 CFR 1910 Subpart S Electrical

OSHA 29 CFR 1926 Subpart I Tools-Hand and Power

OSHA 29 CFR 1910 Subpart P Hand and Portable Powered Tools and Other Hand-Held Equipment

OSHA 29 CFR 1910 Subpart O Machinery and Machine Guarding 
- OSHA 29 CFR 1910.147 The Control of Hazardous Energy (Lockout/Tagout)

- OSHA 29 CFR 1926.52 Occupational Noise Exposure

- OSHA 29 CFR 1910.95 Occupational Noise Exposure

- OSHA 29 CFR 1926.103 Respiratory Protection

OSHA 29 CFR 1910.134 Respiratory Protection

- OSHA 29 CFR 1926.102 Eye and Face Protection

OSHA 29 CFR 1910.133 Eye and Face Protection

OSHA 29 CFR 1926.28 Personal Protective Equipment

- OSHA 29 CFR 1910.132 General Requirements (Personal Protective Equipment)

- ACGIH Threshold Limit Values for Chemical Substances and Physical Agents and Biological Exposure Indices

Best Management Practices:

- ANSI S3.34-1986 Guide for the Measurement and Evaluation of Human Exposure to Vibration Transmitted to the Hand

In addition to the above regulations and policies, it is imperative that all workers have appropriate training for the task and associated safety and health conditions. Training that would be required may be divided into four categories. Core training is that which is required for anyone entering a hazardous waste site to perform work, regardless of the type of job. Technology-specific training is training that is specific to the technology and required by safety and health standards. Special training is that which is specific to the technology to assure the worker is adequately trained for the task but is not necessarily required by safety and health standards. Best management practices involve training that is not mandated by health and safety standards, but which provides information to the worker that will allow the worker to perform his/her job safely. Training to be applied for the heavy-duty roto peen may include but not be limited to:

Core training requirements:

$\downarrow \quad$ HAZWOPER (Hazardous Waste Operations and Emergency Response) 
- HAZCOM (Hazard Communication)

- Radiation Safety (Radiation Worker Training) for radiation sites

Technology-Specific Training:

- Respiratory Protection

Hearing Conservation

- Personal Protective Equipment

$\downarrow \quad$ Electrical Safety

Lockout/Tagout

Special training:

Job specific training for equipment operation

Best Management Practice training:

- Ergonomics (proper lifting, bending, stooping, kneeling, arm-hand vibration)

Heat stress (learning to recognize signs and symptoms)

CPR/First Aid/Emergency Response/Blood-borne Pathogens

Hand Signal Communication

- Construction Safety (OSHA 500) and or General Industry Safety (OSHA 501)

\section{SECTION 6 OPERATIONAL CONSIDERATIONS \& RECOMMENDATIONS}

Recommendations made here for improved worker safety and health take into consideration not only the technology but the equipment is was coupled with. The use of this equipment is inherent in the use of the technology (heavy-duty roto peen) and 
therefore, the system must be evaluated as a whole. Specific recommendations include:

Workers must be aware of the tripping hazards associated with hoses and cords that are necessary to operate the equipment. Keeping these as orderly as possible by compliance with good housekeeping regulations will help avoid injury due to tripping.

- Hoses should be attached with some type of clamping system to reduce the possibility that they will become detached accidentally. The vacuum hoses were taped, not clamped, to the outlet on the pieces of equipment. This could allow the hoses to be pulled loose and create an exposure to the contaminant.

- The operators of the equipment need to be trained in ergonomics to include lifting techniques, bending, stooping, twisting, etc. during equipment operation. The possibility that the small unit (DESCO MiniFlushplate) could be attached to a handle that would allow operation from a standing position, eliminating the need to stoop and/or kneel, should be evaluated. Standing would also eliminate the additional exposure to contaminants the worker is receiving due to the need to kneel on the contaminated surface.

- The operator is not able to tell if there is a problem with vacuum pressure until there is an increase in dust production. This meant that there had to be an increase in exposure to the contaminant before the problem was recognized. A magna/helix gauge on the vacuum unit would have allowed the operator to monitor the vacuum pressure.

- The muffler gets hot, and the worker could be burnt by touching the surface. Workers need to be aware of this potential hazard.

- The weight placed on the front of the EDCO CPU-10-C to help keep the scabbling head in contact with the concrete needs to be permanently mounted on the equipment to keep it from sliding or falling off during operation.. Due to the machine vibration during operation the weight moves, and the operator has to keep adjusting it. This causes an increase of stress on the operator's back due to bending to adjust the weight. In addition, the weight could fall of and cause injury to legs, feet, or toes.

- An open position on the left front axle of the EDCO CPU-10-C is a potential point where fingers/hands could be injured, and needs to be guarded. This could be accomplished by incorporating a guard into the vacuum housing.

- The machine vacuum flow needs to be evaluated to ensure adequacy, or the operator needs to be instructed to slow down and to wait for a predetermined 
amount of time after turning the scabbler off before lifting the head. When the operator moves the machine too quickly, or when the scabbling head is lifted from the floor, there is visible dust generation.

The casing to access the roto peen drum requires removal of nuts using an Allen wrench. This task becomes more difficult as dexterity decreases with certain types of gloves. This could be avoided by using some type of a wing nut on the casing.

Before starting the scabbling project, it is necessary to check the hub-to-floor height using a small ruler to measure a predetermined height $(33 / 8$ inches on the EDCO CPU-10-C). When wearing a full-face respirator this task becomes more difficult due to decreased visibility. This also causes the worker to come in contact with the contaminated surface while trying to see the ruler marks. Instead of a small ruler with standard inch marks, a premarked measuring instrument would make the task easier.

The equipment can run without operator control. The operator was äble to let go of the handle and walk in front of the machine. This could lead to a struck by, contracted by, or caught between accident. The machine needs to be fitted with a dead man switch so that the equipment cannot run without operator control.

Noise exposure was significant during operation of the technology. Since testing was done in an outdoor environment, it is plausible that the noise levels would increase in an enclosed environment. The equipment needs to be evaluated for possible engineering controls to help decrease the noise exposure to the operator. If engineering controls are not possible, administrative controls, and/or adequate hearing protection must be incorporated during operation.

Due to the windy outdoor environment in which the testing demonstration was conducted and therefore, the dust and noise monitoring was conducted, it is recommended that further testing for dust exposure and noise exposure be conducted in an enclosed environment similar to that of a hazardous waste clean-up site. This would also allow for a more thorough evaluation of heat stress while wearing the appropriate PPE.

It is also recommended that the operation and maintenance activities be evaluated while the operator is wearing Level A and Level B PPE, since these levels may be needed in environments where the concrete contamination is mixed in nature or other than radiation.

Many of the safety and health issues discussed throughout this report could be reduced or eliminated by remote operation of the scabbling technology. 


\section{APPENDIX A- REFERENCES}

Occupational Safety and Health Standards for General Industry, 29 CFR Part 1910, Occupational Safety and Health Administration United States Department of Labor, 1995

Occupational Safety and Health Standards for the Construction Industry, 29 CFR Part 1926, Occupational Safety and Health Administration United States Department of Labor, 1995

Threshold Limit Values (TLV's) for Chemical Substances and Physical Agents and Biological Exposure Indices (BEl's), American Conference of Governmental Industrial Hygienists, 1995-1996

ANSI 1986, Guide for the measurement and evaluation of human exposure to vibration transmitted to the hand, New York, NY: American National Standards Institute, ANSI S3.34 


\section{APPENDIX B - INDUSTRIAL HYGIENE DATA}

\section{IH SAMPLING DATA}

\begin{tabular}{|c|c|c|c|}
\hline औ & $\begin{array}{l}3 \mathrm{M} \text { Heavy } \\
\text { Total D }\end{array}$ & $\begin{array}{l}\text { y Roto Peen } \\
\text { Sampling }\end{array}$ & \\
\hline Date & Sample Number & Analyte & ${ }^{*}$ Results \\
\hline $4 / 30 / 96$ & 043096-FIU-001 & Total dust & $0.7463 \mathrm{mg} / \mathrm{m}^{3}$ \\
\hline $4 / 30 / 96$ & 043096-FIU-002 & Total dust & $0.1833 \mathrm{mg} / \mathrm{m}^{3}$ \\
\hline $4 / 30 / 96$ & 043096-FIU-003 & Blank & $0.0000 \mathrm{mg} / \mathrm{m}^{3}$ \\
\hline $5 / 1 / 96$ & 050196-FIU-004 & Total dust & $3.1566 \mathrm{mg} / \mathrm{m}^{3}$ \\
\hline $5 / 1 / 96$ & 050196-FIU-005 & Total dust & $5.4765 \mathrm{mg} / \mathrm{m}^{3}$ \\
\hline
\end{tabular}

* The OSHA PEL for total dust is $15 \mathrm{mg} / \mathrm{m}^{3}$ and the ACGIH TLV is $10 \mathrm{mg} / \mathrm{m} 3$. Current sampling was conducted for total dust. The need to sample for respirable dust and silica has to be considered during concrete decontamination and decommissioning activities. 
Ampli tude Distribution Data

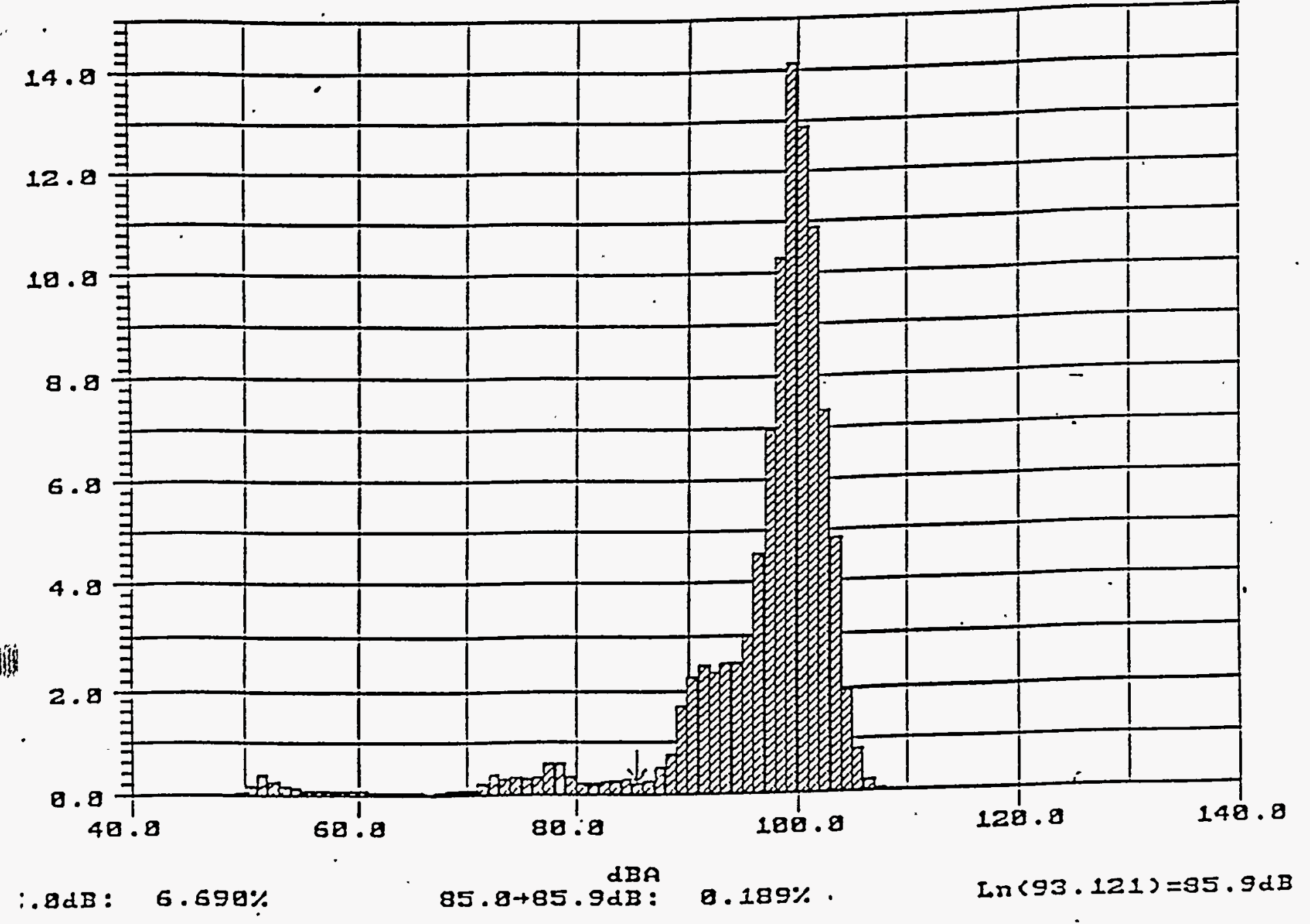

The percentage of time spent at each decibel level can be obtained from the graph. As shown, $6.690 \%$ of the time the noise exposure was less than $85 \mathrm{dBA}$ which means that the majority of the time or $93.310 \%$ of the time the noise exposure was at sound levels above $85 \mathrm{dBA}$. OSHA requires that a hearing conservation program be initiated if the 8-hour TWA is $85 \mathrm{dBA}$. 